University of Nebraska - Lincoln

DigitalCommons@University of Nebraska - Lincoln

USDA National Wildlife Research Center - Staff Publications
U.S. Department of Agriculture: Animal and Plant Health Inspection Service

July 2005

\title{
A test of targeted and passive capture of Australian elapids with a brown tree snake trap
}

Ian D. Temby

Deakin University

Richard M. Engeman

USDA-APHIS-Wildlife Services, s_r100@yahoo.com

Follow this and additional works at: https://digitalcommons.unl.edu/icwdm_usdanwrc

Part of the Environmental Sciences Commons

Temby, lan D. and Engeman, Richard M., "A test of targeted and passive capture of Australian elapids with a brown tree snake trap" (2005). USDA National Wildlife Research Center -Staff Publications. 103.

https://digitalcommons.unl.edu/icwdm_usdanwrc/103

This Article is brought to you for free and open access by the U.S. Department of Agriculture: Animal and Plant Health Inspection Service at DigitalCommons@University of Nebraska - Lincoln. It has been accepted for inclusion in USDA National Wildlife Research Center - Staff Publications by an authorized administrator of DigitalCommons@University of Nebraska - Lincoln. 


\title{
A test of targeted and passive capture of Australian elapids with a brown tree snake trap
}

\author{
Ian D. Temby ${ }^{\mathrm{a}}$, Richard M. Engeman ${ }^{\mathrm{b}, *}$
}

\author{
${ }^{a}$ School of Ecology and Environment, Deakin University, 221 Burwood Highway, Burwood, Vic. 3125, Australia \\ ${ }^{\mathrm{b}}$ National Wildlife Research Center, 4101 LaPorte Ave, Fort Collins, CO 80521-2154, USA
}

Received 14 January 2005; accepted 13 July 2005

All reptiles in Australia receive statutory protection. However, Australia is home to many of the world's most highly toxic venomous snakes, and when these snakes, or similar-looking snakes, come into human proximity, conservation issues are routinely disregarded and the snakes are killed. A secure and effective snake trap could allow dangerously venomous snakes to be removed from the vicinities of humans in safety (for both humans and snake). Towards this end, we conducted a demonstration trial to see if the trap widely used on Guam to capture brown tree snakes (Boiga irregularis) could be applied in a suburban Australian setting to safely remove dangerous snakes without killing them.

Trapping has consistently been a highly effective component in the integrated programme for deterring the mildly venomous brown tree snake from entering into the cargo flow from Guam, and for reclaiming areas on Guam for the reintroduction of endangered birds (Engeman \& Vice, 2001). Brown tree snake traps are custom-designed traps (Linnell et al., 1998; Vice, Engeman, \& Vice, 2005) that employ a funnel trap concept with origins from the 1940s (Imler, 1945). Key to the security of this trap design is the one-way door flap installed at each of

\footnotetext{
*Corresponding author. Tel.: +970266 6091; fax: +9702666089.

E-mail address: richard.m.engeman@aphis.usda.gov (R.M. Engeman).
}

the two funnel entrances (Linnell et al., 1998). The door flaps have specially designed hinge pins so that they swing shut even when the trap is rotated $75-80^{\circ}$ along its horizontal axis, preventing escape (Engeman \& Vice, 2001; Linnell et al., 1998). Within the trap is a compartment where a live mouse is maintained as a visual and olfactory attractant. The mouse is completely separated from captured snakes, resulting in mouse life expectancies similar to that in other captivity settings (Engeman \& Vice, 2001). However, on Guam such traps oftentimes capture brown tree snakes even though no mouse had been installed as an attractant (RE personal observation).

In Australia, if traps are placed in proximity to human activities, the use of the live mouse could draw dangerous snakes into areas where they are not desired. Thus, we tested two mouse-free approaches to trapping in suburban Melbourne to see if a brown tree snake trap would capture elapids even if no mouse was used as an attractant. The first approach was a passive application, with trapping conducted on the ground along an exterior wall such that the entrances might opportunistically intercept snakes that may be traveling along the wall. Two species of elapid were captured. The eastern brownsnake (Pseudonaja textilis), widespread in Australia (e.g., Cogger, 2000), is the most important species in terms of snakebite fatality (Sutherland, 1992), and has the second most toxic venom (to rodents) of any snake species tested 
worldwide (Broad, Sutherland, \& Coulter, 1979; Whitaker \& Shine, 1999). The other species captured, the eastern tiger snake (Notechis scutatus), is also common in southeastern Australia (e.g., Cogger, 2000). It too exhibits among the most highly toxic snake venoms in the world (Broad et al., 1979), and likely is a distant second to brownsnakes for the number of Australian snakebite fatalities (Sutherland, 1992).

Our second approach tested a targeted or active application by using the trap to target snakes that first had been observed. In the first trial of this approach a trap was placed against a hole in a wall where a large tiger snake had sought refuge. The snake had been disturbed by a dog that alerted one of the authors (IT) to its presence immediately outside a home's side door late one evening. The snake was in the trap by the next morning, and was safely released in appropriate habitat away from housing. This second trial of the targeted approach occurred when, subsequent to cutting tall grass, an eastern brown snake was observed entering a gap between a garden shed and the wall of a house. A trap was set in this gap and checked daily. Four days later the snake was in the trap. It also was released safely in suitable habitat on a nearby nature reserve.

Our applications of the brown tree snake trap in both an active and a passive fashion demonstrated the potential for this, or a similar trap design, to safely capture and remove highly venomous snakes in areas where they might endanger human health and safety. Without a safe and effective means of capture, homeowners would place themselves at considerable risk by attempting to catch or kill snakes they encounter on their premises. Typically, capture of such snakes for later release would be too risky for all but the most highly trained people, and snakes would usually be destroyed. For some applications, use of traps with the protected mouse as an attractant, or combined with the use of drift fences, might be tested for an increase in the likelihood of capture.

\section{References}

Broad, A. J., Sutherland, S. K., \& Coulter, A. R. (1979). The lethality in mice of dangerous Australian and other snake venoms. Toxicon, 17, 661-664.

Cogger, H. G. (2000). Reptiles and amphibians of Australia. Sydney, Australia: New Holland Publishers.

Engeman, R. M., \& Vice, D. S. (2001). Objectives and integrated approaches for the control of brown tree snakes. Integrated Pest Management Reviews, 6, 59-76.

Imler, R. H. (1945). Bullsnakes and their control on a Nebraska wildlife refuge. Journal of Wildlife Management., 9, 265-273.

Linnell, M. A., Engeman, R. M., Pitzler, M. E., Watten, M. O., Whitehead, G. F., \& Miller, R. C. (1998). An evaluation of two designs of stamped metal trap flaps for use in the operational control of brown tree snakes (Boiga irregularis). The Snake, 28, 14-18.

Sutherland, S. K. (1992). Deaths from snake bite in Australia, 1981-1991. Medical Journal of Australia, 157, 740-746.

Vice, D. S., Engeman, R. M., \& Vice, D. L. (2005). A comparison of three trap designs for capturing brown treesnakes on Guam. Wildlife Research, 32, 355-359.

Whitaker, P. B., \& Shine, R. (1999). When, where, and why do people encounter Australian brownsnakes (Pseudonaja textilis: Elapidae)? Wildlife Research, 26, 675-688. 